Haagensen, C. D. (1933). American fournal of Cancer, 19, 285

Haagensen, C. D. (1956). Diseases of the Breast, p. 506. Philadelphia, Saunders.

Haddow, A., and Alexander, P. (1964). Lancet, 1, 452.

Hall, J. G., and Morris, B. (1964). Lancet, 1, 1077.

Hamlin, I. M. E. (1968). British fournal of Cancer, 22, 383.

Hultborn, K. A., and Törnberg, B. (1960). Acta Radiologica, Suppl. No. 196,1960

Kister, S. J., et al. (1969). Cancer (Philadelphia), 23, 570.

Lane, N., Goksel, H., Salerno, R. A., and Haagensen, C. D. (1961). Annals of Surgery, 153, 483

Lewis, M. G., et al. (1969). British Medical fournal, 2, 547.

MacCarty W. C. (1922). Annals of Surgery, 76, 9.

MacKay, W. D. and Baum, M (1968). In Prognostic Factors in Breast Cancer, ed. A. P. M. Forrest, and P. B. Kunkler, p. 319. Edinburgh, Livingstone.

Mathé, G. (1969). British Medical fournal, 3, 7.
McDivitt, R. W., Stewart, F. W., and Berg, J. W. (1968). Tumours of the Breast, Atlas of Tumour Pathology, 2nd Series, Fascicle 2, p. 57. Washington, Armed Forces Institute of Pathology.

Moore, O. S., and Foote, F. W. (1949). Cancer (Philadelphia), 2, 635.

Morton, D. L., and Malmgren, R. A. (1968). Science, 162, 1279.

Patey, D. H., and Scarff, R. W. (1928). Lancet, 1, 801

Richardson, W. W. (1956). British fournal of Cancer, 10, 415.

Rissanen, P. M. (1969). British fournal of Radiology, 42, 423.

Schiodt, T. (1966). Breast Carcinoma: A Histological and Prognostic Study of 650 Followed-Up Cases, pp. 79, 157. Munksgaard, Copenhagen.

Stewart, T. H. M. (1969). Cancer (Philadelphia), 23, 1380.

Urban, J. A. (1964). British fournal of Surgery, 51, 209.

Williams, W. J., and Roberts, M. M. (1968). In Prognostic Factors in Breast Cancer, ed. A. P. M. Forrest, and P. B. Kunkler, p. 331. Breast Cancer, ed. A.

Wolff, B. (1966). British fournal of Cancer, 20, 36.

\title{
Haemolytic-uraemic Syndrome Treated with Heparin
}

\author{
MARTIN W. MONCRIEFF,* B.M., M.R.C.P., D.oBST., R.C.O.G. \\ ERIC F. GLASGOW, $\ddagger$ M.B., B.CH., B.A.o.
}

British Medical fournal, 1970, 3, 188-191

\begin{abstract}
Summary: Three children with the haemolytic-uraemic syndrome were treated with intravenous heparin. Peritoneal dialysis was required for two of them, one of whom died after 26 days of therapy. Renal biopsy specimens from the two survivors showed widespread glomerular disease, which appeared permanent in one case, but only occasional thrombi. It is suggested that heparin therapy, by preventing further intrarenal thrombosis, allowed the normal fibrinolytic mechanisms to remove previously formed thrombi.
\end{abstract}

\section{Introduction}

The haemolytic-uraemic syndrome, first described by Gasser et al. (1955), is characterized by acute haemolytic anaemia, thrombocytopenia, and uraemia. The mortality in the acute stage of the illness may be as high as $66 \%$ (Shinton et al., 1964), but with modern management of fluid and electrolyte imbalance the prognosis should improve (Gianantonio et al., 1964). With dialysis patients may now survive after prolonged oliguria (Sharpstone et al., 1968). Heparin therapy has been advocated (Kibel and Barnard, 1964) on the grounds that the pathological changes in the kidneys resemble those found in the Schwartzman phenomenon, in which generalized microthrombi are observed (Verstraete et al., 1965). Heparin appears to have improved the outcome (Table I). Below we present data on three children suffering from the haemolytic-uraemic syndrome whom we have treated with intravenous heparin in the past six months.

\section{Case 1}

An 11-year-old boy was admitted to the City General Hospital, Stoke-on-Trent, with a history of vomiting for two days. He had slight facial oedema and a blood pressure of 190/120 mm. $\mathrm{Hg}$. He was anaemic, uraemic, and had thrombocytopenia; fragmented red cells and burr cells were present in a peripheral blood film. A diagnosis of the haemolytic-uraemic syndrome was made and heparin therapy was started. In view of the development of severe oliguria and a rising blood urea level, however, he was transferred two days later to the Children's Hospital. The results of further investigations (Table II) confirmed the diagnosis.

\footnotetext{
*Lecturer in Paediatrics and Child Health, Institute of Child Health, Birmingham University. At present Consultant Paediatrician, Derbyshire Children's Hospital, Derby.

+Senior Research Fellow in Renal Disease, Department of Pathology, Children's Hospital, Birmingham 16.
}

TABLE I-Patients With the Haemolytic-Uraemic Syndrome Treated With Heparin $(13$ Additional Patients Treated With Heparin Were Reported by Gianantonio et al. (1967), but the Number of Survivors is Not Recorded).

\begin{tabular}{|c|c|c|c|}
\hline \multicolumn{2}{|l|}{ Authors } & No. Treated & No. Surviving \\
\hline 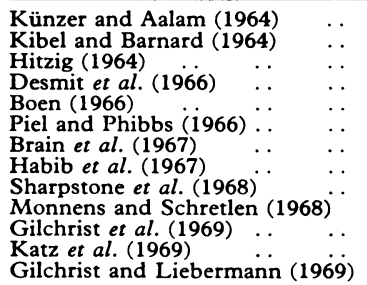 & $\begin{array}{l}\because \\
\therefore\end{array}$ & $\begin{array}{l}1 \\
1 \\
4 \\
1 \\
1 \\
3 \\
3 \\
3 \\
2 \\
4^{*} \\
8 \\
4 \\
2\end{array}$ & $\begin{array}{l}1 \\
1 \\
3 \\
1 \\
1 \\
2 \\
1 \\
1 \\
2 \\
2 \\
2 \\
7 \\
2 \\
2\end{array}$ \\
\hline Tot & & 37 & 27 \\
\hline
\end{tabular}

* One patient received streptokinase before heparin.

TABLE II.-Laboratory Findings in Three Cases of Haemolytic-Uraemic Syndrome

\begin{tabular}{|c|c|c|c|}
\hline & Case I & Case II & Case III \\
\hline 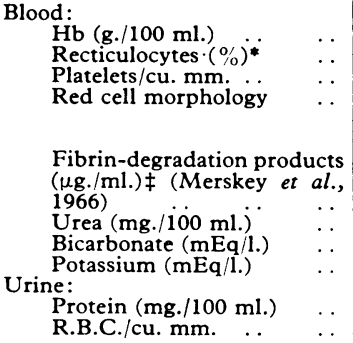 & $\begin{array}{c}4 \cdot 5 \\
16 \\
175,000+ \\
\text { Fragmented } \\
\text { cells and } \\
\text { Burr cells } \\
\\
30 \\
450 \\
16 \\
5 \cdot 5 \\
1,000 \\
6\end{array}$ & $\begin{array}{c}6 \cdot 2 \\
16 \\
38,000 \\
\text { Fragmented } \\
\text { cells and } \\
\text { Burr cells } \\
\\
\text { Not measured } \\
315 \\
23 \cdot 5 \\
4 \cdot 5 \\
1,000 \\
80\end{array}$ & $\begin{array}{c}7 \cdot 3 \\
14 \cdot 4 \\
95,000 \\
\text { Fragmented } \\
\text { cells and } \\
\text { Burr cells } \\
\\
27 \\
324 \\
11 \\
7 \cdot 7 \\
\text { Anuric } \\
\text { Anuric }\end{array}$ \\
\hline
\end{tabular}

* Maximum count recorded during the illness.

tHe had already received heparin therapy.

$\ddagger$ Normal levels for our laboratory: mean $3.7 \mu \mathrm{g} . / \mathrm{ml}$., range $0-8 \mu \mathrm{g} . / \mathrm{ml}$.

Intravenous heparin therapy was continued, being given sixhourly in an initial dose of 8,000 units, the subsequent doses being adjusted to maintain the blood-clotting time between 20 and 30 minutes. He was transfused with $1,000 \mathrm{ml}$. of whole blood, and peritoneal dialysis was started. He developed congestive cardiac failure owing to increasing hypertension, which was treated with parenteral guanethidine and later oral bethanidine. His urine output steadily declined and he was completely anuric from the tenth day after admission. The next day he became delirious, three days later he had a generalized convulsion and thereafter he remained drowsy and confused. His blood urea fell steadily and was maintained around $100 \mathrm{mg} . / 100 \mathrm{ml}$. by dialysis for eight hours a day. His platelet count remained above $100,000 / \mathrm{cu}$. mm., except on two 
occasions when heparin was discontinued in preparation for renal biopsy. On each occasion the platelet count was found to be below $50,000 / \mathrm{cu}$. $\mathrm{mm}$. and renal biopsy was not performed. On the 24th day after admission he had a large haematemesis, inhaled some vomit, and died a few hours later.

At necropsy (by Dr. A. R. Goldsmith) there was pronounced hypertrophy of the left ventricle with dilatation of both atria, and both kidneys were enlarged, a few punctate haemorrhages appearing on the surface. On histological examination all glomeruli showed considerable amounts of periodic-acid/Schiff (P.A.S.)-positive material diffusely arranged throughout the glomerulus associated with a mild degree of cellular proliferation (Fig. 1). Capillary walls were thickened and some glomeruli were enlarged. Several small arteries and arterioles showed replacement of the intima and to some extent the media with P.A.S.-positive fibrinoid material, and often the lumen was occluded (Fig. 2). There were prominent eosinophilic casts in dilated proximal tubules and occasional mononuclear cell aggregations were present in the interstitium.

\section{Case 2}

A 7-year-old girl was admitted to Burton General Hospital with diarrhoea followed by vomiting, oliguria, and pallor. She had anaemia, thrombocytopenia, and uraemia, and fragmented red cells and burr cells were present in the peripheral blood film. A diagnosis of haemolytic-uraemic syndrome was made, and next day she was transferred to the Children's Hospital. Her blood pressure was $120 / 70 \mathrm{~mm}$. Hg. and she had no oedema. The liver was palpable $2 \mathrm{~cm}$. below the right costal margin and the spleen was just palpable. The results of investigations (Table II) confirmed the diagnosis.

She was treated with blood transfusion and intravenous heparin by continuous infusion, initially being given 8,000 units of heparin in 24 hours and the dose being gradually increased to 12,000 units daily so that by the third day the blood-clotting time had risen to between 20 and 30 minutes. Heparin therapy was continued for a week. Her platelet count rose to $110,000 / \mathrm{cu}$. mm. on the third day and thereafter remained above $100,000 / \mathrm{cu}$. $\mathrm{mm}$. The course of her illness is shown in Fig. 3. The blood urea reached a maximum of $464 \mathrm{mg} . / 100 \mathrm{ml}$. on the fourth day, but neither uraemic symptoms nor acidosis developed and the serum potassium rose to only $5.4 \mathrm{mEq} / \mathrm{l}$., so that dialysis was not required. During the oliguric phase she was treated with restricted fluid intake and low-protein diet. From the third day onwards she passed increasing quantities of urine and the blood urea fell steadily. After the diuresis she made an uneventful recovery. Before discharge her creatinine clearance was $65 \mathrm{ml} . / \mathrm{min} . / 1.73$ sq.m.; her urine contained no blood and only $130 \mathrm{mg}$. of protein in 24 hours.

Percutaneous renal biopsy was performed 25 days after admission and, though all glomeruli showed changes, these varied from one to another and in localized areas within the glomeruli. There was much increase in fibrillar mesangial material and associated hypercellularity, mainly in the mesangium. Some proliferation of capsular epithelium was noted with occasional crescents, and there

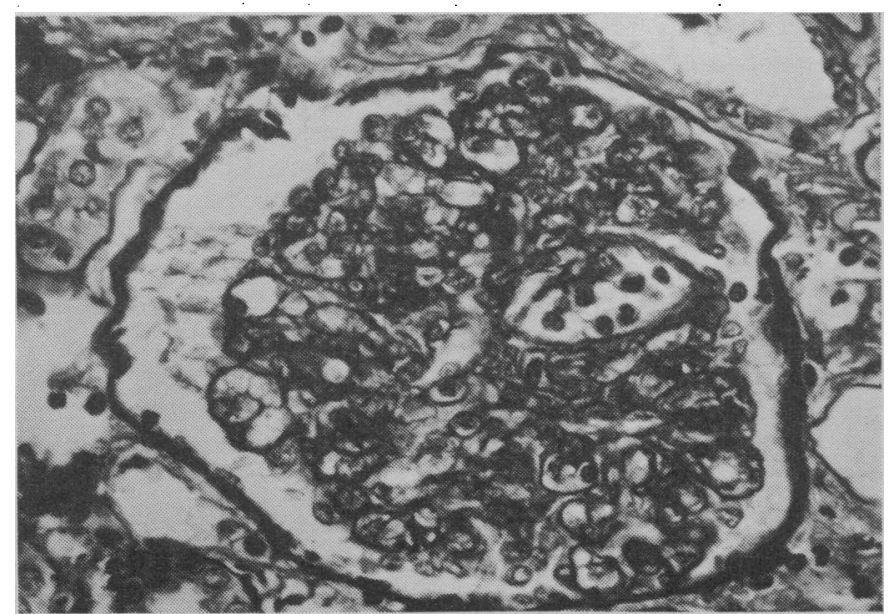

FIG. 1-Case 1. Glomerulus from necropsy showing diffusely arranged increase of P.A.S.-positive material. (P.A.S. $\times$ 385.)

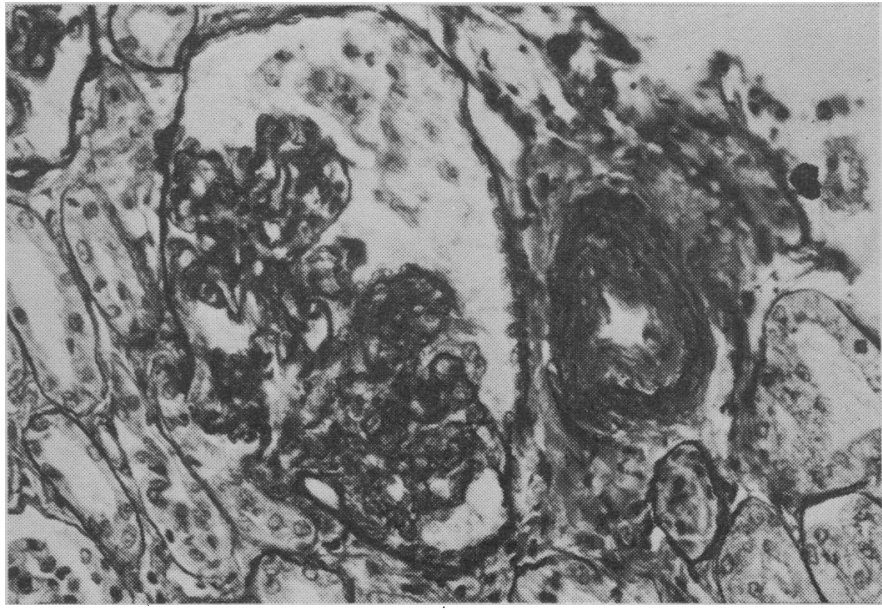

FIG. 2.-Case 1: Glomerulus from necropsy showing diffusely arranged increase of P.A.S.-positive material and an adjacent arteriole with replacement of intima. (P.A.S. $\times 240$.)
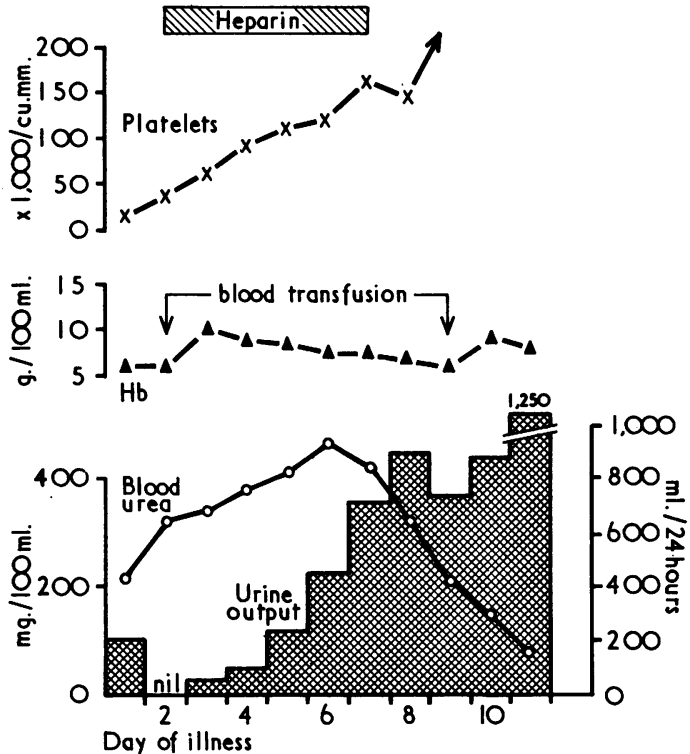

Fig. 3.-Case 2. Course of illness.

were scattered adhesions (Fig. 4). In preparations stained with periodic-acid/silver methenamine the basement membrane of capillary loops was thickened and duplicated in places. Occasional areas of interstitial fibrosis were seen but no vascular occlusion was noted.

\section{Case 3}

A 1-year-old boy developed diarrhoea and vomiting and on the next day had a generalized convulsion and became anuric. On admission to Cheltenham General Hospital he was found to be anaemic and uraemic, and a peripheral blood film contained fragmented red blood cells. A diagnosis of the haemolytic-uraemic syndrome was made and he was transferred to the Children's Hospital the same day. He was unconscious but responded to painful stimuli, and had occasional convulsive movements of his limbs. He was very pale but not jaundiced, and his blood pressure was $90 / 60 \mathrm{~mm}$. $\mathrm{Hg}$. The results of investigations (Table II) confirmed the diagnosis.

He was treated with peritoneal dialysis, intravenous heparin, and blood transfusion. The course of illness is shown in Fig. 5. Heparin was given in an initial dose of 1,000 units and thereafter in varying doses every six hours, the aim being to maintain the whole-blood clotting-time between 20 and 30 minutes. After six days of this treatment the platelet count rose above $100,000 / \mathrm{cu}$. mm. With dialysis the blood urea fell steadily and his general condition improved. He remained anuric for five days and oliguric for a 


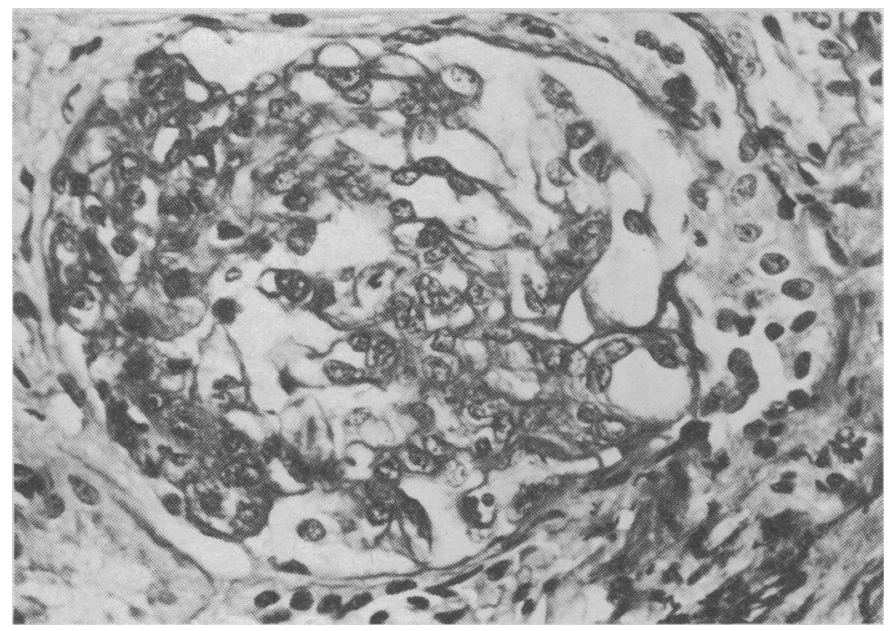

FIG. 4.-Case 2. Glomerulus in renal biopsy showing increased mesangial matrix and associated hypercellularity with crescent formation. (P.A.S. $\times 385$.)
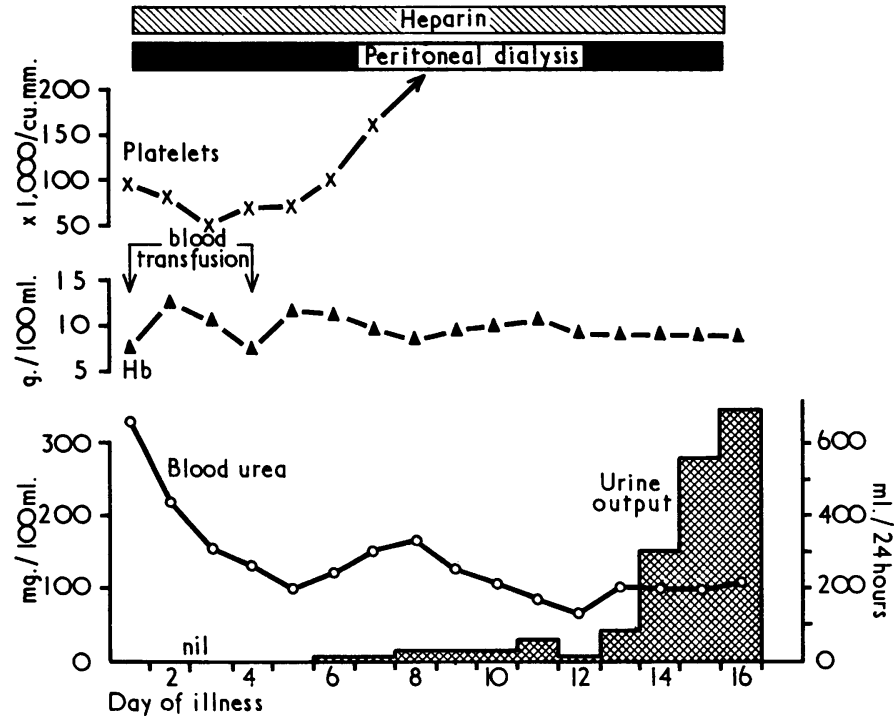

Fig. 5.-Case 3. Course of illness.

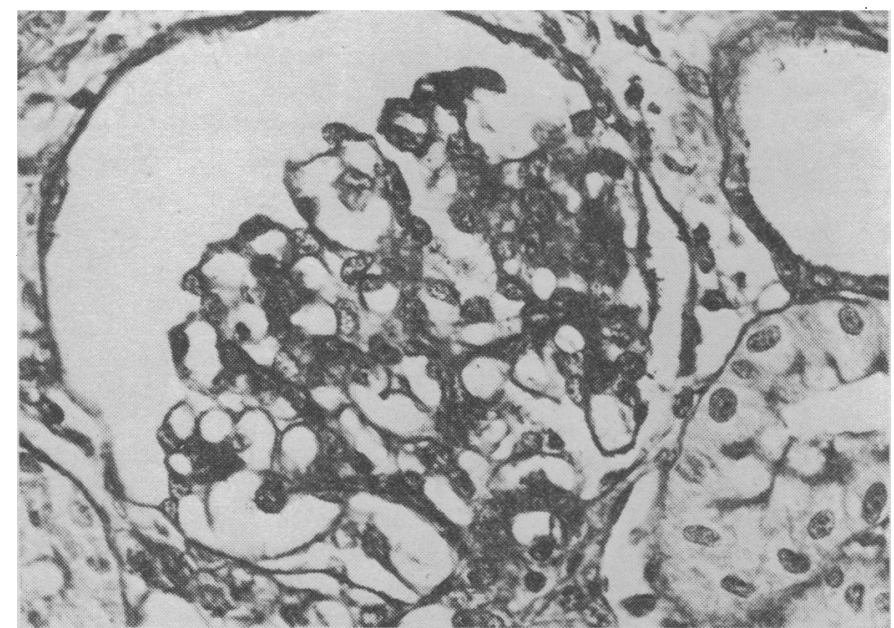

FIG. 6.-Case 3. Glomerulus representative of one-third of those in renal biopsy (two-thirds of the total glomeruli were sclerotic) showing excess of P.A.S.-positive mesangial material and contraction of the glomerulus (P.A.S. $\times$ 385.)

further eight days. Thereafter his urinary output returned to normal and dialysis was discontinued after 15 days. At discharge his blood urea was $93 \mathrm{mg} . / 100 \mathrm{ml}$. and his urine did not contain protein or red blood cells.
Two weeks after heparin therapy was discontinued percutaneous renal biopsy was performed. Two-thirds of the glomeruli were represented by structureless eosinophilic masses, often containing haemosiderin. Of the remaining glomeruli, most contained an excess of P.A.S.-positive material in the mesangium and were contracted with large cystic capsular spaces (Fig. 6). Some of the capsules showed epithelial hyperplasia but no crescents were seen. Rarely, occluded arterioles were seen adjacent to glomeruli. The interstitium was increased in amount mainly owing to oedema and showed haemosiderosis and mild histiocytic infiltration.

\section{Discussion}

Though the cause of the haemolytic-uraemic syndrome is unknown many of the clinical manifestations are thought to be due to intravascular coagulation (Piel and Phibbs, 1966). Intrarenal capillary thrombi were found in all the cases examined at necropsy by Shinton et al. (1964) and by Liebermann et al. (1966). Increased disappearance of ${ }^{131}$ Ilabelled fibrinogen was found in one patient by Brain et al. (1967), and fibrinogen breakdown products were present in this patient and in one of the patients reported by Gilchrist et al. (1969). These findings support the concept that intravascular coagulation occurs in the haemolytic-uraemic syndrome. Heparin has been shown to be effective in treating diseases characterized by intravascular coagulation (RodriguezErdmann, 1965) and its use in the haemolytic-uraemic syndrome seems logical. Treatment with heparin is usually followed by a rise in the platelet count which suggests that platelet consumption occurs in conjunction with intravascular coagulation in this disease. The results of heparin therapy reported in the literature are shown in Table I and though the mortality remains high, these patients were probably very severely affected and would be expected to have little chance of recovery. Gilchrist et al. (1969) reported eight deaths among 22 patients before the introduction of heparin therapy, whereas there was only one death among eight patients treated with heparin.

Intravenous heparin was given to our three patients in an initial dose of 100 units per $\mathrm{kg}$. Thereafter it was given to Cases 1 and 3 at six-hourly intervals, the dose being adjusted according to the blood-clotting time measured two hours after each injection. We found it difficult to keep the clotting time constantly between 20 and 30 minutes as recommended by Gilchrist et al. (1969), and it fluctuated between 5 and 90 minutes. Anticoagulant therapy, however, was effective as judged by the rise in the platelet count. There were no bleeding episodes in Case 3, but Case 1 had a large terminal gastro-intestinal haemorrhage. The blood-clotting time was not measured on the day of death, but the dose of heparin had not been increased, and the platelet count on the previous day was only $48,000 / \mathrm{cu}$. $\mathrm{mm}$. It is therefore impossible to say whether the thrombocytopenia or the anticoagulant therapy was mainly responsible for this haemorrhage. Because of this episode of bleeding in Case 1, heparin was given to Case 2 by continuous intravenous infusion. The clotting-time, however, took 48 hours to reach 20 minutes and this method seems less effective in a situation which demands urgent action. Heparin was therefore given to Case 3 by intermittent injection. Treatment was discontinued in Cases 2 and 3 once a diuresis was established. As noted in other reports (Piel and Phibbs, 1966; Sharpstone et al., 1968) we tound it difficult to control the effects of heparin therapy whether it was given by intermittent injection or by continuous intravenous infusion. Perhaps the most physiological method of administration would be by constant infusion pump, though this requires more elaborate equipment.

Examination of the kidney in Case 1 showed widespread and severe glomerular damage. This patient had required peritoneal dialysis for 23 days, being completely anuric for the last 14 days. Recovery after this period of anuria must be unusual, though two of the three cases with prolonged oliguria 
described by Sharpstone et al. (1968) did not have a diuresis until between three and four weeks after the onset of anuria. Histological examination in Case 2 showed generalized glomerular involvement of only moderate severity, which we feel will ultimately resolve. Case 3 , however, had severe damage of about two-thirds of the glomeruli, and though he survived the acute illness he may eventually develop chronic renal insufficiency. This has been reported in as many as $30 \%$ of patients who survive the acute illness (Gianantonio et al., 1968). Detailed renal histology, in patients treated adequately with heparin, has previously been reported in only two cases; one had widespread glomerular damage and thrombotic lesions (Hitzig, 1964), and the other had essentially normal glomeruli (Piel and Phibbs, 1966).

The reports of heparin therapy are too few for its usefulness to be assessed, and a controlled trial planned to take into account the variable severity of the disease is required. Examination of renal histology in our Cases 2 and 3, however, suggests that heparin therapy was beneficial, for, despite widespread glomerular damage, only occasional thrombotic lesions were seen. These findings suggest that severe renal damage had occurred before the institution of heparin therapy, but that further intrarenal thrombosis was prevented by heparin, allowing removal of existing thrombi by the normal fibrinolytic process. We agree with Dacie (1957) that the further use of heparin in treatment of the haemolytic-uraemic syndrome is warranted, but we believe that more information about its effects could be obtained if post-treatment evaluation included an examination of the renal histology in survivors as well as those who succumb.

We are grateful to Dr. J. G. Dathan, Dr. R. D. C. Johnstone, and Dr. R. D. G. Creery for kindly referring these patients; to Dr. R. H. R. White, under whose care they were admitted, for his encouragement and advice; to Dr. J. Stuart and the staff of the naematology department for their help; and to Dr. A. H. Cameron and the staff of the pathology department for help with the interpretation and preparation of the histological material.

\section{REFERENCES}

Boen, S. T., (1966). In European Dialysis and Transplant Association: Proceedings of the 2nd Conference on Renal Failure and Replacement of Renal Function, edited by D. N. S. Kerr, p. 75. Amsterdam, Excerpta Medica.

Brain, M. C., Baker, L. R. I., McBride, J. A., and Rubenberg, M. (1967). Quarterly fournal of Medicine, 36, 608 .

Dacie, J. V., (1967). The Haemolytic Anaemias, 2nd ed., p. 875. London, Churchill.

Desmit, E. M., Hart, H. C., Helleman, P. W., and Tiddens, H. A. W. M. (1966). In European Dialysis and Transplant Association: Proceedings of the 2nd Conference on Renal Failure and Replacement of Renal Function, edited by D. N. S. Kerr, p. 68. Amsterdam, Excerpta Medica.

Gasser, C., Gautier, E., Steck, A., Siebermann, R. E., and Oechslin, R., (1955). Schweizerische medizinische Wochenschrift, 85, 905.

Gianantonio, C., Vitacco, M., Mendilaharzu, F., Rutty, A., and Mendilaharzu, J. (1964), fournal of Pediatrics, 64, 478 .

Gianantonio, C., Vitacco, M., and Mendilaharzu, F. (1967). In Proceedings of Third International Congress of Nephrology, edited by L. E. Becker, Vol. 3, p. 24. Basel, Karger.

Gianantonio, C. A., Vitacco, M., Mendilaharzu, F., and Gallo, G. (1968). Fournal of Pediatrics, 72, 757.

Gilchrist, G. S., and Liebermann, E. (1969). Lancet, 2, 1069.

Gilchrist, G. S., Liebermann, E., Ekert, H., Fine, R. N., and Grushkin, C. (1969). Lancet, 1, 1123 .

Habib, R., Mathieu, H., and Royer, P. (1967). Nephron, 4, 139.

Hitzig, W. H. (1964). Helvetica Paediatrica Acta, 19, 213.

Katz, J., Lurie, A., and Kaplan, B. (1969). Lancet, 2, 700.

Kibel, M. A., and Barnard, P. J. (1964). Lancet, 2, 259

Künzer, W., and Aalam, F. (1964). Lancet, 1, 1106.

Liebermann, E., Heuser, E., Donnell, G. N., Landing, B. H., and Hammond, G. D. (1966). New England fournal of Medicine, 275, 227.

Merskey, C., Kleiner, G. J., and Johnston, A. J. (1966). Blood, 28, 1.

Monnens, L., and Schretlen, E. (1968). Lancet, 2, 735.

Piel, C. F., and Phibbs, R. H. (1966). Pediatric Clinics of North America, 13, 295.

Rodríguez-Erdmann, F. (1965). New England fournal of Medicine, 273,

Sharpstone, P., Evans, R. G., O'Shea, M., Alexander, L., and Lee, H. A. (1968). Archives of Disease in Childhood, 43, 711.

Shinton, N. K., Galpine, J. F., Kendall, A. C., and Williams, H. P. (1964). Archives of Disease in Childhood, 39, 455.

Verstraete, M., Vermylen, C., Vermylen, J., and Vandenbroucke, J. (1965). American fournal of Medicine, 38, 899.

\title{
Routine Induction of Labour by Amniotomy and Simultaneous Syntocinon (Synthetic Oxytocin) Infusion
}

\author{
MICHAEL E. PAWSON, ${ }^{*}$ M.B., B.S., M.R.C.O.G. ; STANLEY C. SIMMONS,† F.R.C.s., M.R.C.o.G.
}

\begin{abstract}
Summary: Of 2,272 deliveries between 1 October, 1967 and 31 December, 1968290 were induced by simultaneous intravenous Syntocinon (synthetic oxytocin) at amniotomy. The hazards of induction of labour are greatly reduced when this method is used routinely. Only 4 of the 13 caesarean sections were thought to be due to failure of method. Within 12 hours 221 patients were delivered, and this short induction-delivery interval resulted in an extremely low maternal and fetal morbidity. It is believed that with proper safeguards and in the light of present knowledge this is the method of choice.
\end{abstract}

\section{Introduction}

Induction of labour by amniotomy and simultaneous Syntocinon (synthetic oxytocin) infusion shortens the induction delivery interval and appreciably reduces the incidence of failure. This, in turn, lowers the incidence of infection (both fetal and maternal) and caesarean section.

A preliminary trial of this method as a routine indicated

- Registrar.

tConsultant.

Windsor and Slough Obstetric Unit, Upton Hospital, Slough, Bucks. that hazards of induction could be greatly reduced (Garud and Simmons, 1968). The results from 1 October 1967 to the end of 1968 confirm our original findings, and for that reason they are presented. The total experience is derived from over 950 cases.

\section{Method}

Labour was induced in $290(12.7 \%)$ of 2,272 deliveries. The indications are shown in Table I. After routine preparation and premedication with pethidine, forewater rupture was performed at 9 a.m. Simultaneously, intravenous Syntocinon

TABLE I.-Indications for Induction

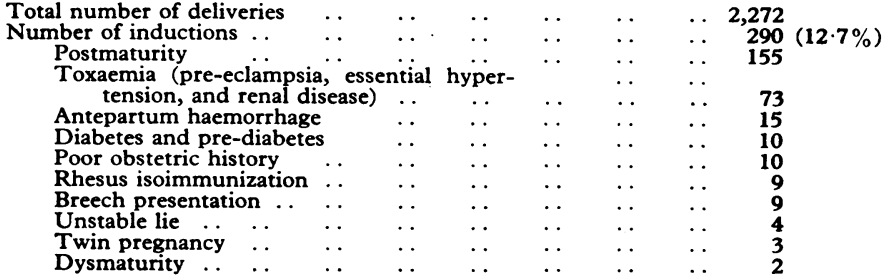

